Nassau Music Society \& The College of The Bahamas present

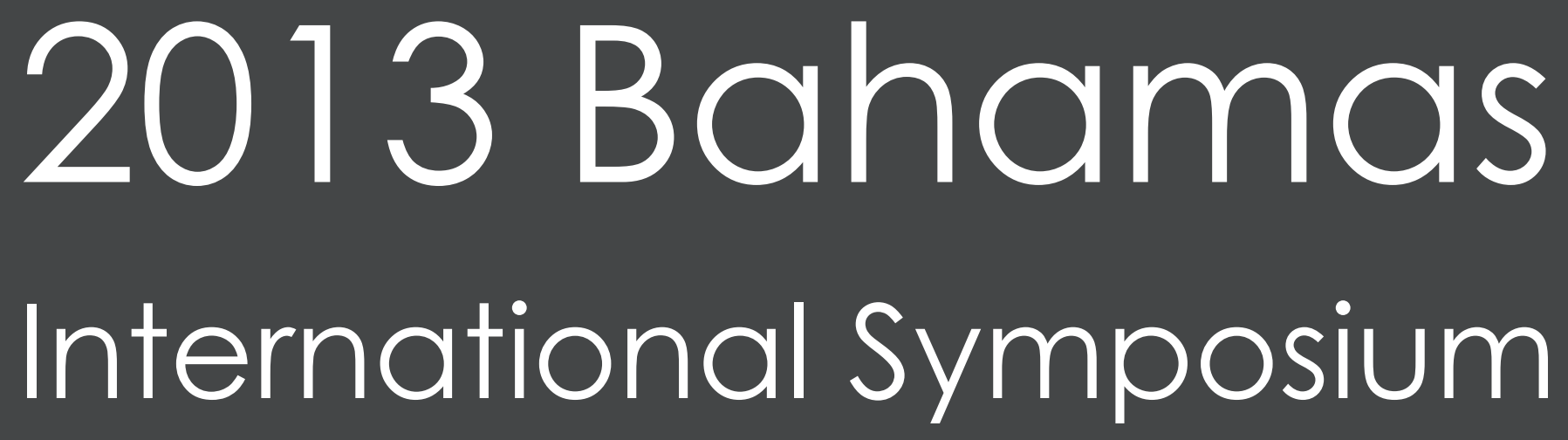

on composers of African \& Afro-Caribbean descent

Thursday, February 21, 2013

The Harry C. Moore Library

and Information Centre Auditorium

The College of The Bahamas 


\section{Bahamas International Symposium}

on composers of African \& Afro-Caribbean descent

Symposium coordinators: Dr. Christine Gangelhoff and Marlon Daniel https://doi.org/10.15362/ijbs.v19i2.208

\section{Table of Contents}

Description...............................................

2013 Symposium

About the Artist: Jeffrey Major

Special Guests: Quatuor Mahogany

Symposium Schedule..................................2

Participant Bios I..............................................

Cleophas Adderley

Peter Ashbourne

Edward Bethel

Participant Bios II

Nicolette Bethel

Carlos R. Carrillo-Cotto

Christine Chalcol

Participant Bios III..........................................

Marlon Daniel

Christian Justilien

Participant Bios IV. 6

Dominique Le Gendre

Christine Gangelhoff

Participant Bios V.

Fred Onovwerosuoke

K. Quincy Parker

Paul Shaw

Participant Bios VI.

Léo Koby Véro

Adam Walters

Audrey Dean-Wright

Notes 


\section{Description}

\section{Symposium}

The 2013 Bahamas International Symposium will engage musicians, composers, and scholars from all over the world in presentations, performances, and conversations around composers and performers of African and Afro-Caribbean descent. It will be organized around the theme Caribbean Art Music: An Unexplored Tradition.

Musical genres associated with the Caribbean typically include popular and traditional styles. Although many composers of art music have emerged from Caribbean nations and from the Caribbean Diaspora, information on this subject is scarce. As composers are slowly gaining recognition, a new understanding of and visibility for Caribbean art music is emerging. The mission of this symposium is to explore this topic of regional and international interest, drawing perspectives from a wide range of disciplines.

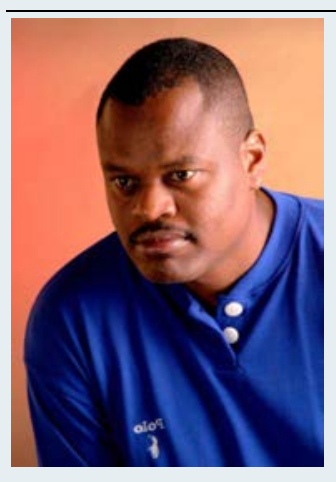

\section{About the Artist: Jeffrey Major}

Bahamian photographer Jeffrey Major has generously contributed the cover art on the symposium program. His works will be displayed between sessions throughout the symposium.

Born in New Providence, Jeffrey Major was educated at the A.F. Adderley High School. Passionate about photography (especially landscape), he has been shooting for five years. One of his greatest influences is Peter Lik, a landscape photography master. Major also loves seascapes and capturing the sunrise and sunset of the Bahamas, which he has done throughout New Providence and in some of the Out Islands. His works have been displayed at Popop Studio and the Wine and Art Festival in Nassau, and as a part of the Transforming Spaces Annual Art Tour. In addition to photography, Major is also greatly involved in cycling, especially in assisting and training youth. He has been primarily responsible for raising the level of the sport in the Bahamas.

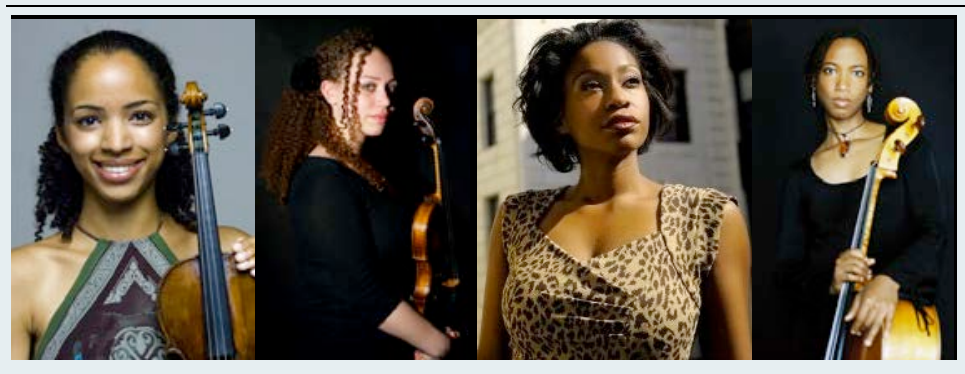

\section{Special Guests: Quatuor Mahogany}

Anyango Yarbo-Davenport, violin I

Shelby Yamin, violin II | Tia Allen, viola

Tahirah Whittington, cello

Quatuor Mahogany was established in 2010 as four members of Ensemble du Monde joined together with the objective to perform chamber music on the highest level and bring more diversity to the classical music world.

Each member of the quartet, in addition to performing with Ensemble du Monde as being Quartet-inResidence and members of the Ensemble, have separate solo careers and perform with other ensembles which include Cicada Chamber Players, CORE Ensemble, Ritz Chamber Players, and The Young Eight.

The members hold degrees from some of the most prestigious music schools in the world including University of Salzburg 'Mozarteum', Eastman School, The Juilliard School, Manhattan School of Music, University of Cincinnati College-Conservatory, New England Conservatory and have performed in international music festivals that have included Aspen, Castleton, Graz and Salzburg to name a few.

Collectively they have performed on six continents and countries that include Argentina, Austria, Australia, Brazil, China, Dominican Republic, France, Germany, Ghana, Japan and Oman.

The members of Quatuor Mahogany have performed with such diverse artists as Alicia Keys, Donnie McClurkin, Kanye West, Regina Carter, Lorin Maazel, Seymour Lipkin, Paul Gemignani, George Manahan, Wynton Marsalis, Phillipe Entrement, Jaime Loredo, Kurt Mazur, Angie Stone, Cee-Lo Green and Joe. 


\section{Symposium Schedule}

11:00AM - 12:15PM

Session 1

\section{Cultural Identity In Bahamian Art Music: The Expression Of Four Bahamian COMPOSERS}

Moderator: Edward Bethel

Guest speakers: Cleophas Adderley, Audrey Dean-Wright, Christian Justilien, K. Quincy Parker

In this session, four prominent Bahamian composers will discuss their pieces, focusing on their compositional style and how/if cultural identity is a strong component of their works. Featured compositions will be demonstrated with audio/video-recorded examples.

12:15PM - 1:30PM

SYMPOSIUM LUNCH

$1: 30 P M-2: 45 P M$

Session II

\section{Perspectives On Composers And Performers Of African Descent In Classical Music}

Moderator: Nicolette Bethel

Guest speakers: Cleophas Adderley, Carlos Carrillo-Cotto, Marlon Daniel, Dominique LeGendre, Paul Shaw

Special guest: Quatuor Mahogany (Saint-Georges Quartet in G Minor, Op. 14, No. 6)

In this session, Caribbean art music will be examined from diverse angles. Perspective from composers, conductors, and activists as well as various international views will provide multiple perspectives on this topic.

2:45PM - 3:00PM

\section{BREAK}

3:00PM - 4:00PM

Session III

\section{International Roundtable Discussion: Diversity In Classical Music}

Moderator: K. Quincy Parker

Panel: Cleophas Adderley, Peter Ashbourne, Carlos Carrillo-Cotto, Marlon Daniel, Dominique LeGendre,

Paul Shaw, Léo Koby Véro, Adam Walters

K. Quincy Parker leads an open discussion on classical and art music as filtered through the African and Afro-Caribbean perspective. 


\section{Participant Bios I}

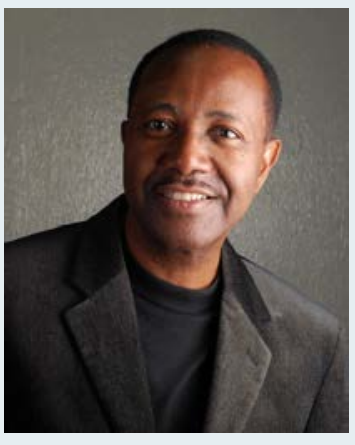

\section{Cleophas AdDerLeY}

Executive Director - National Musical Heritage and Research at the Ministry of Youth, Sports, and Culture.

Cleophas Adderley is a pillar in the cultural development of The Bahamas. He is currently Executive Director, National Musical Heritage and Research at the Ministry of Youth, Sports and Culture, Government of the Commonwealth of The Bahamas. He is the Founder/Director of The Bahamas National Youth Choir, one of the foremost Bahamian cultural institutions that represent The Bahamas both nationally and internationally.

Adderley is a prolific composer. He has written for piano, pipe organ, choir, and solo voice. Hal Leonard Corporation, USA, has published several of his works. He wrote the first Bahamian concert mass "Missa Caribe," and his opera "Our Boys" is the first grand opera to have been written and performed in the English speaking Caribbean. He is the recipient of many awards for his work in the arts including The Distinguished Citizen Award and an award from the International Chapter of Alpha Kappa Alpha Sorority.

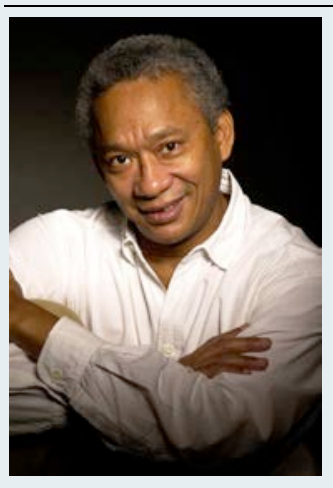

\section{Peter Ashbourne}

Senior Music Fellow - The University of the West Indies, Mona

Peter Ashbourne is one of Jamaica's leading contemporary composers. Also an a accomplished arranger and song-writer, outstanding performer, band leader and record producer, Ashbourne's achievements in the fields of classical music, jazz, and popular forms have greatly assisted the advancement of musical excellence in Jamaica. Born in Kingston, Ashbourne attended the Jamaica School of Music and the University of the West Indies before graduating with a bachelor's degree in Composition and Arranging from the Berklee College of Music in Boston. He is a licentiate of the Royal Schools of Music in violin.

Over the years he has composed music for choirs, soloists, string quartets, chamber music groups, orchestras, wind symphony orchestras and big bands. He is also a veteran musical contributor to the local dance and theatre, as well as to the Caribbean advertising industry. Ashbourne wrote the Reggae Opera 'Mikey', based on the life of dub poet Mikey Smith, which was completed in 2008. In 2012 he was awarded the Order of Distinction - Commander Class (CD) by the Jamaican Government in recognition of his "dedicated and outstanding service to the development of many genres of music in Jamaica".

He is currently a faculty member at the School of Music at the Edna Manley College of the Visual and Performing Arts, a director of the Music Unites Jamaica Foundation and was appointed to the position of Senior Music Fellow by the University of the West Indies in January 2013.

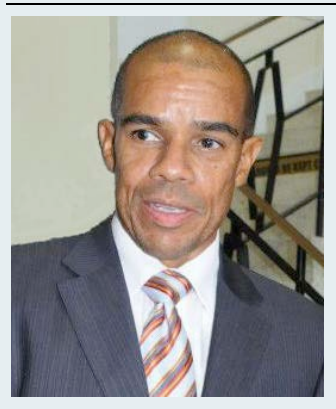

\section{EDWARD BETHEL}

Director of Distance Education - The College of The Bahamas

Edward Bethel is the Director of Distance Education at The College of The Bahamas. Mr. Bethel is a PhD Candidate in Education Technology at Concordia University in Montreal, Quebec, having spent his entire twenty-five year career in education at the secondary and tertiary level. Music and culture has been a central theme in Mr. Bethel's life from a very early age, having participated in Junkanoo almost every year since 1970, the same year he had his first formal piano lesson. Since then, Mr. Bethel has played in bands, sung in, written for and directed choirs, and participated in theatre both onstage and backstage. Mr. Bethel has particularly fond memories of opportunities to perform nationally and internationally as a member of the Dicey Doh Singers, though the recurring highlight of his cultural life is "going to Bay" each Boxing Day and New Year's mornings. 


\section{Participant Bios II}

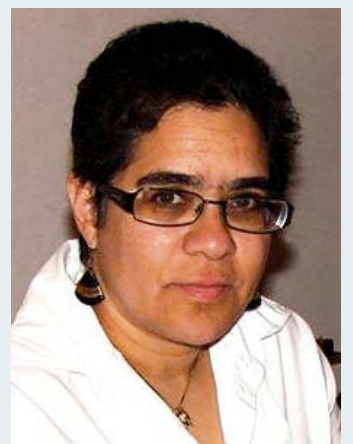

\section{Nicolette Bethel}

Assistant Professor of Sociology - The College of The Bahamas, Head of the Department of Psychology, Sociology and Social Work in the School of Sciences

Nicolette Bethel is a Bahamian who has lived, studied and worked in the UK and Canada. She holds a PhD and an MPhil in Social Anthropology from the University of Cambridge and a BA from the University of Toronto. Bethel is a researcher in the fields of Bahamian kinship, Bahamian national identity and Junkanoo, and is a working poet, playwright, and theatre producer. She served as Director of Culture for the Bahamas for five years, and is currently Assistant Professor of Sociology at the College of The Bahamas, and is Head of the Department of Psychology, Sociology and Social Work in the School of Sciences.

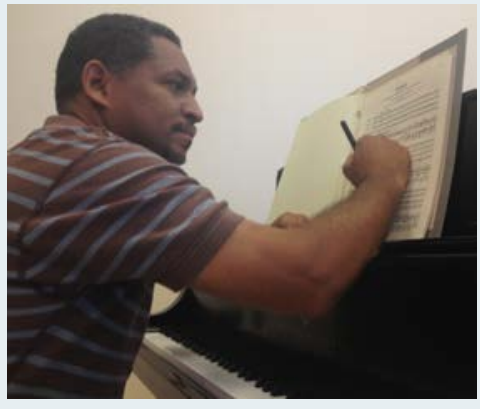

\section{Carlos Carrillo-Cotto}

Assistant Professor of Music - University of Illinois, Urbana-Champaign; Assistant Professor - Conservatorio de Musica de Puerto Rico

Born in San Juan, Puerto Rico, Composer Carlos R. Carrillo-Cotto holds degrees from the Eastman School of Music (BM), Yale University (MM) and the University of Pennsylvania (PhD). His teachers have included Tania León, Joseph Schwantner, Christopher Rouse, Jacob Druckman, Martin Bresnick, Roberto Sierra, George Crumb, James Primosch, Jay Reise and Steve Mackey.

$\mathrm{He}$ is the recipient of the Bearns Prize, the Charles Ives Scholarship from the American Academy of Arts and Letters, the Aaron Copland Award, the Van Lier Emerging Composer Fellow with the ACO, In the Civitella Ranieri Foundation Fellowship and both the BMI and ASCAP Awards. This spring he was a finalist for the 2012 Rome Prize.

He has been commissioned by the Da Capo Chamber Players, the New York Youth Symphony, Concert Artists Guild and the Pennsylvania Music Teachers Association, the American Composers Orchestra, the Casals Festival and Puerto Rico Symphony Orchestra to name a few.

He has taught composition at DePauw University, Reed College, and the Conservatory of Music in San Juan, Puerto Rico and is currently Assistant Professor of Composition-Theory at the University of Illinois at Urbana-Champaign.

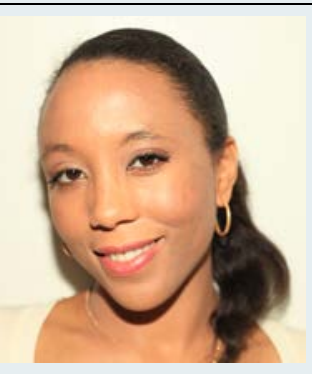

\section{Christine Chalcol}

Director of Educational Outreach - Festival International Saint-Georges

Originally from Guadeloupe, Christine Chalcol is a graduate of the University of Musicology and the Conservatoire National de Region Tours. She also holds a second degree and certification in Complementary Art History from L'Academie Orléans-Tours.

In 2007, after earning a diploma from the Training Center for Musicians Speakers Tours, she received her practical training at Rector of the Academy of Guadeloupe. She also taught elementary school music education and created several innovative lesson plans dedicated to teaching young people about Caribbean music in relationship to other musical forms and styles. Her commitment to education continues through her teaching at IUFM new programs and CAPES external musicology in Guadeloupe where she is a professor of Music Education and Choral Singing.

Currently, she is the Director of Educational Outreach and Representative of the Festival International SaintGeorges in Guadeloupe. 


\section{Participant Bios III}

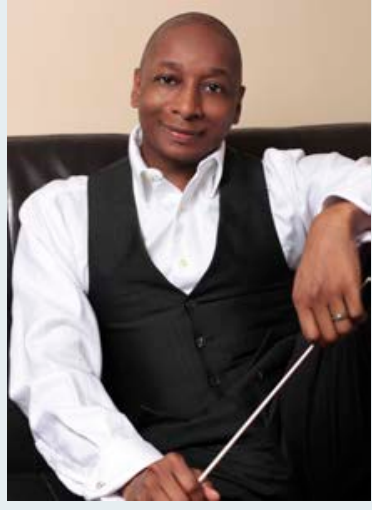

\section{MARLON DANIEL}

Music Director - Ensemble du Monde; Principal Guest Conductor - Sofia Sinfonietta

One of the most dynamic conductors of his generation, Marlon Daniel has been described as "a natural and enormous talent" (Chicago Sun-Times) and his artistry has been hailed as "fabulous and exceptional" (Pravda-Moscow). The winner of the 2009 John and Mary Virginia Foncannon Conducting Award, he has performed in some of the most prestigious venues in Europe and the United States that range from Carnegie Hall to the Rudolfinum in Prague and several international music festivals. He has also appeared alongside several internationally renowned artists that have included Deborah Voigt, Julian Milkis, Koh Gabriel Kameda and Magali Léger to name a few.

He has received numerous prizes and awards including the Mabel Henderson Memorial Grant for Foreign Experience, a Rose Hanus Fellowship, an Honorary Key to the City of Chicago for Outstanding Musical Achievement bestowed by the late Mayor Harold Washington and most recently the 2008 'Voice of the Artist' Award from the United Nations in recognition of his charitable work of bringing awareness to the crisis in Darfur. Most recently he was the recipient of the 2010 Dove Award from the Global Association of Women for the Arts for Outstanding Musical Achievement.

Educated in both the United States and Europe, he has earned degrees from some of the most prestigious institutions in the world including Manhattan School of Music, Le Conservatoire Américain (France), Centro de Estudios Musicales Isaac Albéniz (Spain) and both the Prague Academy and Conservatory, where he received his formative training in conducting whilst serving as Associate Conductor of the Praga Sinfonietta. He has also worked with Sir Simon Rattle and the Berlin Philharmonic as winner of the James and Lola Faust Fellowship.

One of the foremost exponents of music by composers of African and African American descent, Marlon Daniel is also Artistic Director of the Saint-Georges International Festival in Guadeloupe and Principal Conductor of the Festival of African and African American Music, where he collaborates with some of the most prolific Black composers of today in their world premiere new works.

The former Associate Conductor of the Praga Sinfonietta, Maestro Daniel is currently Music Director of Ensemble du Monde and Principal Guest Conductor of the Sofia Sinfonietta.

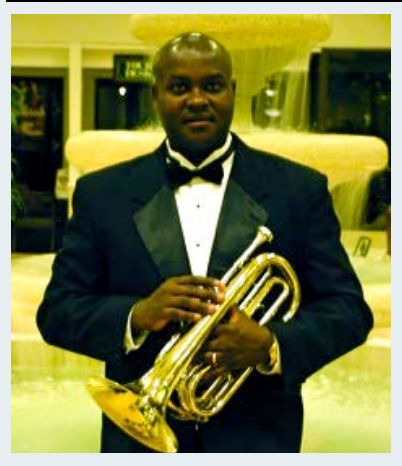

\section{ChRISTIAN JUSTILIEN}

Assistant Professor (Band Director) - The College of The Bahamas; Leader -

AMBASAH (Jazz/ Caribbean Band); Leader - Colours Entertainment \& Junkanoo

Organization; Motivational speaker; Member - The C-Force Chamber Ensemble.

Christian Justilien received a BA in Professional Music Studies from the Berklee College of Music in Boston, where he was the founding director of the Berklee Caribbean Ensemble, and a MEd from the VanderCook College of Music in Chicago, Illinois resulting in an educational website on "Musicians \& Entertainers of The Bahamas."

He is actively involved in his community and projects geared towards the advancement of young people and the preservation of Bahamian culture. Justilien has produced four recordings of traditional Junkanoo music; three with Roots, and one more recently with his award winning group Colours.

His latest composition "Bahama Islands Suite" written for C-Force vividly captures the discovery, historical events, and the spirit of the islands of The Bahamas. 


\section{Participant Bios IV}

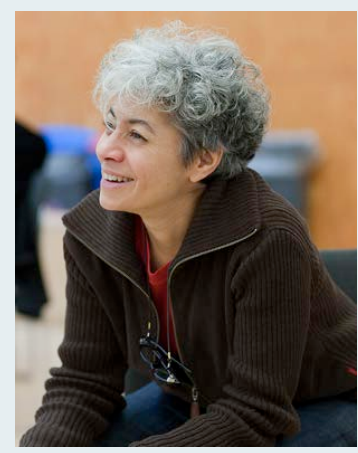

\section{DOMINIQUE LE GENDRE}

Associate Artist - The Royal Opera House

UK based Caribbean composer Dominique Le Gendre was born in Trinidad where she lived until the age of 19, at which point she left to study music in Paris. She trained as a classical guitarist with Ramon de Herrera who encouraged her to acknowledge her unique identity as a Caribbean musician - an identity which has evolved to become an integral part of her musical language.

This language has served her as she wrote extensively for theatre, BBC radio drama, film, television and dance over the twenty-five years that she has been living in London. She wrote and produced all the music for Arkangel's recordings of The Complete Shakespeare directed by Clive Brill. Since the appearance of her 15-minute Opera "Bird Of Night" at the Linbury theatre as part of NITRO AT THE OPERA in November 2003, she was named Associate Artist of the Royal Opera House. Her full-length opera, "Bird of Night" directed by Irina Brown, was commissioned by the ROH and premiered in October of 2006.

Her chamber works have been commissioned and performed by The ROH chamber soloists, The Philharmonia Orchestra, The Manning Camerata, Lontano Orchestra, Tête-a-tête Opera, Ibis Ensmble and British cellist Tony Woollard amongst others.

She has been Associate Artist to the Manning Camerata led by ROH concertmaster, Peter Manning Their 1st major collaboration, a Dramma per Musica of Seamus Heaney's "The Burial at Thebes", directed by Derek Walcott, premiered in the autumn of 2008 at Liverpool8 and Shakespeare's Globe Theatre in London.

In August 2012 she co-curated with producer and curator Melanie Abrahams, "London Is The Place For Me Festival", for the Trinidad and Tobago High Commission's London celebration of Trinidad and Tobago's 50th anniversary of Independence.

She is currently workshopping a new piece of music-theatre in Trinidad, "Jab Molassie" with a libretto by Double Bassist Caitlyn Kamminga. The piece, inspired by Stravinsky's "Soldier's Tale", has been commissioned by Calabash Foundation for the Arts and sets the universal Faustian tale in Trinidad using carnival characters and including a double-tenor steel-pan in the 9-piece ensemble.

Other current projects include a one-year creative engagement project inspired by Estauries and in collaboration with practical philosopher Ayisha De Lanerolle, creative producer Kate Theophilus, Chef Sarah Saunders and LAB Director Susan Benn. She is also researching, developing and creating a number of new theatre and music-theatre projects, salons and symposia in collaboration with Jamaican writer Pat Cumper.

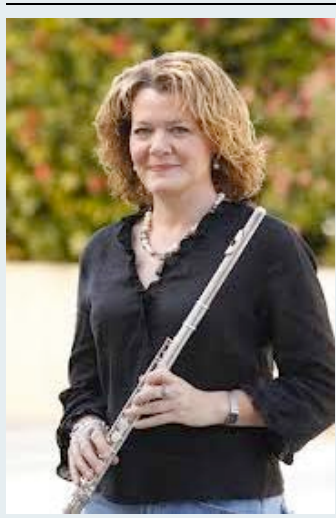

\section{Christine Gangelhoff}

Assistant Professor of Music - The College of The Bahamas; Member - The C-Force Chamber Ensemble

Dr. Christine Gangelhoff has been a member of the music faculty of The College of The Bahamas since 2007. Previously, she served on the faculties of Memorial University of Newfoundland and St. Thomas University in St. Paul, Minnesota. She holds degrees from Yale University, the University of Minnesota, and the University of North Texas.

As a flautist Dr. Gangelhoff has established her career through solo and chamber performances in the United States, Canada, the Caribbean, and Europe. As an orchestral player, she has performed with the Minnesota Orchestra, St. Paul Chamber Orchestra, Oregon Symphony, Portland Ballet, and the Vancouver Island Symphony.

In addition to performing, Dr. Gangelhoff has done extensive research on art music from the Caribbean region. The first volume of her bibliography on Caribbean art music received The College of The Bahamas Stanley Wilson award for Excellence in Research in 2012. She continues to work on subsequent volumes as she seeks to promote a deeper understanding of and greater visibility for this little-known tradition. 


\section{Participant Bios V}

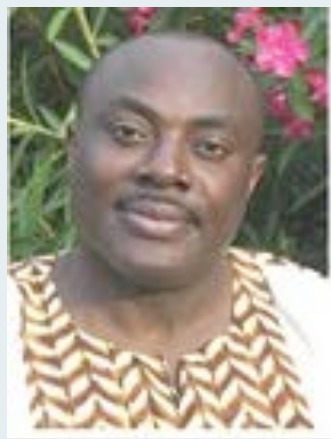

\section{Fred ONOVWEROSUOKE}

Funder and Artistic Director - intercultural Music Festival

The founder and director of African Musical Arts Inc., Composer Fred Onovwerosuoke's diverse background has given rise to a varied compositional style. Born in Ghana to Nigerian parents, he grew up in both countries and eventually naturalized in the United States. "FredO", as friends call him, has traveled in more than thirty African countries doing fieldwork and analyzing some of Africa's abundant music traditions.

His works have been featured in audio recordings, films, documentaries and radio, including Robert De Niro's film, The Good Shepherd, William-Chapman Nyaho's CD, ASA and Hymes/Hollister's CD African Art Music for Flute. His new book, Songs of Africa: 22 Pieces for Mixed Choirs, published by Oxford University Press, has quickly become a favorite among choral directors across the United States and globally. His other significant publications are distributed by the African Music Publishers and on Amazon.com. He also serves on several boards and is a voting member of The Recording Academy and other professional bodies, editor of the Voice of African Music newsletter since 1993 and a founding trustee of the International Consortium for Music of African \& its Diaspora (ICMAD). Onovwerosuoke maintains an active schedule as conductor, lecturer, cross-cultural educator, and composer.

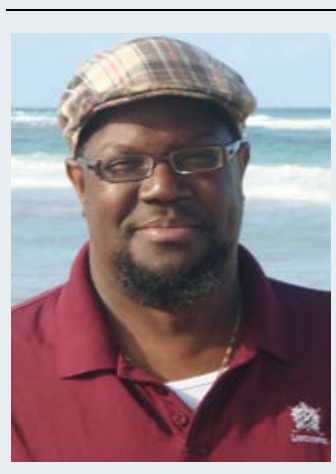

\section{K. QUINCY PARKER \\ Composer and Arranger}

Bahamian K. Quincy Parker is a composer, singer, guitarist, teacher and arranger. $\mathrm{He}$ began his musical journey in The Bahamas as a producer of hip hop in a MIDI studio owned and operated by Neil Symonette, one of the world's finest percussionists. Neil introduced him to jazz, which eventually led him to major in guitar performance at Oral Roberts University. After a semester at ORU, he discovered his true calling composition. Quincy went on to earn an honours degree in Music Composition at ORU, graduating as the Outstanding Composition Student in his year (along with his close friend and colleague Lydia Ashton) after winning the 20th Century Composition Contest in his junior year. His dream was, and has been, to write for film, but he has written everything: choral masses, oratorio, opera, symphony, concerti, and chamber music. He has written music for the film industry in The Bahamas as well as for both the Highgrove Singers and Bel Canto Singers, two of Nassau's best known vocal ensembles. One of the highlights of being a musician for him is being able to make music with his wonderful wife, Suzette.

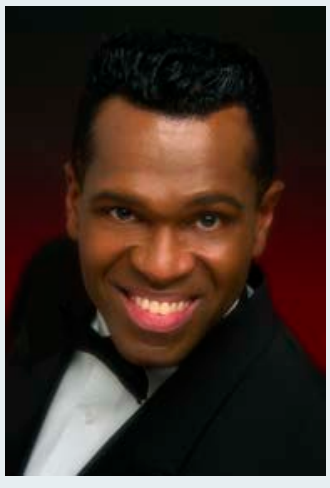

\section{PAUL SHAW}

Associate Professor - The University of Minnesota School of Music

Hailed by The New York Times as "both a virtuoso with herculean technical command and a sensitive introspective artist," Jamaican pianist Paul Shaw has performed at Carnegie Hall in New York; the Kennedy Center in Washington, D.C.; and Beethovenhalle in Bonn. The holder of three degrees including the Doctor of Musical Arts from The Juilliard School, Shaw is a veritable champion of music from the African Diaspora. In 2010 he was the first artist from the Caribbean to appear at the National Centre for the Performing Arts in Beijing, China, performing an entire recital of solo piano works from his Caribbean Art Music compact disc: Le Grand Tour, including Bahamian composer Cleophas Adderley's Variations on a Theme by E. Clement Bethel. As Head of the Keyboard Division at the University of Minnesota School of Music, Dr. Shaw continues research and advocacy for art music inspired by his Caribbean heritage, most recently completing eight transcriptions of Jamaican folk songs for solo piano. Upcoming projects include a Latin American and Caribbean tour in the 2015-2016 season. 


\title{
Participant Bios VI
}

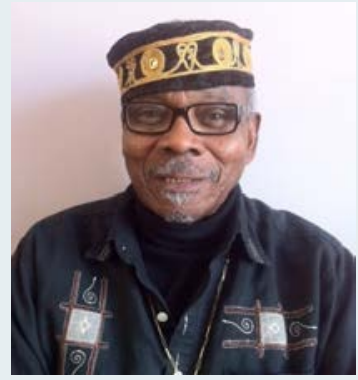

\author{
LÉO KobY VÉRO \\ Founder and President - Cénacle du Chevalier de Saint- George
}

A native of Cayenne in French Guyana, Léo Koby Véro made his professional debut as a trumpeter in 1954. He was the founder and principal trumpet of "The New School Jazz" from 1955 to 1956 and from 1956 to 1958 was principal trumpeter of the "Gerro's Bop" orchestra and performed in the Antonio Lucio quintet.

In 1959 he relocated to Paris where he decided to continue his musical studies at the Conservatoire Municipal "Hector Berlioz", École Normale Supérieure de Musique de Paris, Université Internationale de Musique and the Conservatoire de Paris Rueil Malmaison. He continued to perform with such ensembles as Orchestre Noir et Blanc and Les Oyampis.

In 1965, seeking to enhance music education in his native Guyana, he created the first music school in Guyana, the Eudomir Cabéria Music School. In 2005 he founded the Cénacle du Chevalier de SaintGeorge, a non-profit organization whose mission is to revitalize the life and music of Le Chevalier de SaintGeorge, and to support the performance of other composers and performers of African descent.

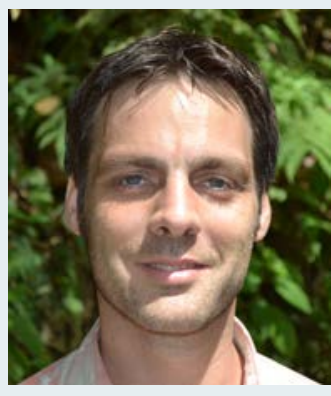

\section{AdAM WALTERS}

French Horn Section Leader - The Academy for The Performing Arts, University of Trinidad and Tobago

Adam Walters works at the Academy for the Performing Arts, which is part of the University of Trinidad and Tobago. He studied music at Cambridge University and the Royal College of Music before working as a French horn player based in London. He has become increasingly busy as a composer since moving to Port of Spain. His musical re-telling of Little Red Riding Hood (2011) for lbis Ensemble was made into a book in collaboration with Trinidadian artist Che Lovelace. Adam's piece "The Old Yard: Carnival Portraits from Trinidad" (2012) - with poetry by Muhammad Muwakil and photography by Maria Nunes - was premiered at last year's Bocas Literary Festival at the University of Trinidad and Tobago, and further performances are in the planning stages. In these works, as in pieces he has written for local students, Adam has drawn upon aspects of Trinidadian culture as the starting point for his compositions. Adam is working towards a PhD in composition (Royal Holloway, University of London) using Trinidadian musical influences.

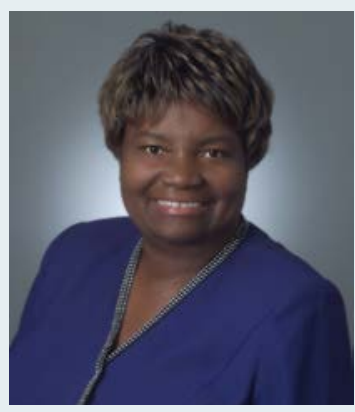

\section{Audrey DeAN-WRight}

Associate Professor and Head of Visual \& Performing Arts - The College of The Bahamas

Bahamian born Audrey Dean-Wright has been a part of the fabric of music and culture of The Bahamas for over 40 years. She received her early piano training under the tutelage of Muriel Mallory, Meta Cumberbatch, and, her mentor, E. Clement Bethel. She continued her music training at the Jamaica School of Music, Kingston, Jamaica and Manhattan School of Music, New York, where she received the Bachelor and Masters of Music degrees. Mrs. Wright is one of The Bahamas' most prolific composers having composed over 250 compositions in a variety of genres, including compositions for solo voice, choir, flute and piano. Her works have been performed in the USA, the Caribbean, Europe, and most recently in China, in July of 2012.

As the first non-American composer to be a featured composer with the Southeast African American Collegiate Festival, she has had the honour of conducting leading historically black university choirs in her original works. Her piano, choral and poetry compositions have been used as test pieces in the E. Clement Bethel National Arts Festival, The Bahamas. Mrs. Wright has written three books that are in use in the public schools in The Bahamas: "Children Sing For Joy", a collection of 31 songs for children with accompaniment CD; "Audrey's Favourite Bahamian Songs and More", and "'he Young Pianist", a collection of piano pieces. Her collection of flute pieces, "Flutescapes", with performance CD, will be released next spring. 